\title{
Development of accounting information system and accounting standards for small and medium enterprises (SME)
}

\author{
Endang Satyawati ${ }^{1,},{ }^{*}$, Mujiyono $^{1}$ \\ ${ }^{1}$ The Faculty of Economics, Universitas Kristen Surakarta, J1.Monginsidi No.36-38, \\ Surakarta, Jawa Tengah, Indonesia
}

\begin{abstract}
At this time, small and medium enterprises play an important role in improving the economy of Indonesia, in terms of business number, job creation, and growth of national Economy. At this time many small, and medium enterprises are still in the manual recording process of financial transactions and financial reporting. The objective of this study is to develop an accounting information system method with Rapid Application Development (RAD) for SME as to answer whether there is an increased quality of information system in SME. The results of this research are as follows: 1) The small business enterprises are dominated by human resources. 2). Many of the owners of the small business enterprises do not understand the accounting and financial report system well. They operate with manual and conservative descriptions with a simple book noted. They have not known or have not been accustomed to computerized accounting system as well as have not known whether or not it is useful to support their business continuity. 3) Personal expenses and operational expenses paid by using the same sources.

Keywords: Accounting Information System, Rapid Application
\end{abstract} Development, Accounting Standards, SME

\section{Introduction}

The Indonesian economy is experiencing erratic fluctuations, which makes the small and medium enterprises become a good vehicle for the creation of productive employment as the production process of the small and medium scale industries are generally laborintensive. Until now, the micro, small, and medium scale enterprises play an important role in improving the economy of Indonesia in terms of businesses number, job creation, and national economic growth. The small and medium enterprises is one of the keys for this nation out of the crisis, because in majority the businesses related to the real sectors are the micro, small, and medium enterprises, and most people believe that one of the keys for this nation to out of the crisis is by driving the real sectors.

\footnotetext{
*Corresponding email: endangsatyawati@uks.ac.id
} 


\subsection{Accounting Information System}

At this many small, and medium enterprises are still in the manual recording process of financial transactions and financial reporting. It is not effective and efficient in business operations. The manual system often goes wrong, especially if the transaction data are abundant, which may cause the financial information presented to be not accurate, relevant, and timely.

The development of technology, especially technology information, which instrumental in all fields is very fast. In the field of business, information technology is very favorable for the survival of companies. The companies rely on information systems to maintain their competitiveness. The development of information technology is expected to improve the enterprises' progress in their business. The small and large scale enterprises need information system immensely as they need a system, which connect between the units there. The system is very important to support the activities of the companies so as to increase their productivity.

The application of information technology in the enterprises has a very large role, especially in the management and processing of data. The information generated by a computer-based information system, will meet the needs of the users. A good information system is a system of mutual support sub-systems, and is equipped with sophisticated computers.

The use of computer technology in accounting information systems or socalled Electronic Data Processing (EDP) will help improve the efficiency and effectiveness of the system itself. However, this condition can be met provided that specially made software or special applications must meet the accurate and true standards of internal control procedures. Computer technology is not only used by large companies, but with the rapid advancement in technology and the need for fast and precise information, the small and medium scale companies also need to improve the effectiveness of the work. The small, and medium enterprises in improving their business require a support for the daily operation data processing.

The rapid technological development and the need for accurate, relevant, and timely information are expected by the internal and external users of information of the companies. However, in reality there are still many SMEs which use manual systems in their data processing operation. They require a support of computer technology. The use of manual systems with an emphasis on human power can lead to several problems as follows:

1. The data processing takes long time

2. The calculation contains errors or inaccuracy

3 . The results of data processing are not timely reported

4. The data security is improperly guaranteed

\subsection{Accounting Standards}

Outline of systems relating to the current major accounting standards In Indonesia, Articles 66 to 69 of the Company Act stipulate the contents and procedures of financial statements that should be included in the annual report. Companies are required to prepare their financial statements in accordance with the accounting standards established by the Indonesian Accountants Association, Ikatan Akuntan Indonesia (IAI).

As for accounting standards for SME, Standar Akuntansi Keuangan untuk Entitas Akuntabilitas Publik (SAK-ETAP) established the accounting standards for Non Publicly Accountable Entities (ETAP) in 2009. The standards have been applied from the fiscal year 
starting 1 January 2011. IFRS has been applied since 2012, but IFRS for SME is not completely adopted as the accounting standards in Indonesia. However, in the process of developing the Tier2 SAK ETAP standards, the Indonesian Financial Accounting Standards Board, an organisation inside the Institute of Certified Public Accountants (DSAK IAI), has referred to IFRS for SME and is incorporating important points in the country's accounting standards. Other related movements include IAI's announcement of the Exposure Draft of Accounting Standards for Small and Medium Entities (ED SAK UKM) in December 2008, which incorporated some amended concepts of IFRS for SME into SAK ETAP. 2017 [1]

\section{Theory and Development of Hypotheses}

\subsection{Contributions Small, and Medium Scale Enterprises (SMEs) to Economy}

Law No. 2008 regards SMEs as a legal basis and support for the empowerment of SMEs. The statistic shows that the number of units of SMEs approaches $99.98 \%$ of the total business units in Indonesia. The contribution of SMEs to economy is clearly shown by its dominance as much as $99.04 \%$ to provide jobs. Similarly, its contribution to the Gross Domestic Product (GDP) of non-oil is quite convincing that is $63.11 \%$. The role of SMEs in Indonesia as well as in other countries is the backbone of the national economy.

Table 1: Contribution of Small and Medium Scale Enterprises (SMEs) in Some Countries

\begin{tabular}{|l|l|l|l|l|l|l|}
\hline No. & Country & Year & $\begin{array}{c}\text { The } \\
\text { contribution } \\
\text { of SMEs to } \\
\text { employment }\end{array}$ & $\begin{array}{c}\text { The } \\
\text { contribution } \\
\text { of SMEs to } \\
\text { GDP }\end{array}$ & $\begin{array}{c}\text { The } \\
\text { contribution } \\
\text { of SMEs to } \\
\text { export }\end{array}$ & $\begin{array}{c}\text { SMEs } \\
\text { contribution } \\
\text { to total } \\
\text { business } \\
\text { units }\end{array}$ \\
\hline 1 & China & 2008 & $75 \%$ & $60 \%$ & $68 \%$ & $99 \%$ \\
\hline 2 & India & 2012 & - & - & $40 \%$ & $90 \%$ \\
\hline 3 & Japan & 2007 & $69 \%$ & $53 \%$ & - & $99.7 \%$ \\
\hline 4 & $\begin{array}{l}\text { South } \\
\text { Korea }\end{array}$ & 2009 & $75 \%$ & $60 \%$ & - & $99.9 \%$ \\
\hline 5 & Singapore & - & $70 \%$ & $60 \%$ & - & $99 \%$ \\
\hline 6 & Malaysia & 2012 & $56 \%$ & $32 \%$ & $19 \%$ & $99.2 \%$ \\
\hline 7 & Thailand & 2010 & - & $37.1 \%$ & $28.4 \%$ & $99.8 \%$ \\
\hline 8 & Philippines & 2009 & $61.2 \%$ & $35.7 \%$ & - & $99.6 \%$ \\
\hline
\end{tabular}

The table shows that SMEs have an important role in the economic and industrial system of each country. The efforts to empower SMEs have been made through (1) improved access to funding, (2) increased productivity and competitiveness, and (3) increased exports.

\subsection{Development of Accounting Information System}




\subsubsection{System}

System is an entity or a unit which consists of interconnected parts (sub-systems), which is aimed to achieve certain goals 1996 [2]. Information is output (output) of a data processing. This output usually is in good order and has meanings for those who receive it so that it can be used as a basis for decision-making 1996 [3]. Information also means significant and useful knowledge to achieve a particular goal or objective 1993 [4]. Meanwhile, according to Henry C.Lucas, "Information is either visible or invisible fact which is available to reduce uncertainty about some circumstances or events. 2000 [5]

\subsubsection{Definition of Accounting Information System}

Accounting Information System is a composition of various forms, records, equipment including computers and equipment as well as communications equipment, implementation personnel, and reports which are closely coordinated and which are designed to transform the financial data to information required by the management.

The accounting system and the accounting information system have the same idea, namely: a series of administrative activities to handle corporate transactions so that they are uniform. They both are equipped with a variety of procedures, documents and journals where their results are financial reports for internal and external uses 1994 [6]. The accounting system utilizes the existing resources within the company, namely: employees, automatic machines, computers and other resources. The accounting system can be carried out manually (by utilizing the employees and support automated machines such as copy machines, calculators, and typewriters) or by computerized ones (by using computers).

System development process is a set of activities, methods, best practices, automated delivery process and equipment used by the stakeholders to develop and improve information system and software continuously 2001 [7]. The stakeholders here can be defined as ones who are interested in or attracted to the existence of an information system or to a new information system. The stakeholders can be technical or non-technical personnel. In information system, the stakeholders can be the owners, users, analysts, designers, builders, sellers of the system as well as information technology consultants.

\subsubsection{Information System Development Method}

Rapid Application Development (RAD) is a system development strategy that prioritizes the acceleration in the system development through extensive user involvement in the use of a construction sequence, where the circuit serves as a more effective system model (prototype).

The system development process frequently uses prototyping. This method is best used to solve misunderstanding between the users and analysts, which usually occurs due to the inability of the users to clearly define their needs

Prototyping is the rapid development and the testing of work models (prototypes) of new applications through a repeated interaction process which is frequently used by information system experts and business experts. Prototyping is also called rapid application design (RAD) because it simplifies and accelerates the design of the system $2005[8]$. 
Some users are difficult to express their wishes to get applications that fit their needs. These difficulties need to be resolved by the analysts to understand the users' needs and translate them into the form of a model (prototype). This model is further improved continuously to suit the users' needs.

Based on its characteristics, the prototype of a system can include low fidelity and high fidelity. Fidelity refers to the level of detail in a system.

Low fidelity prototype does not describe the system detailed enough. The characteristics of the low fidelity prototype include the following: having limited function or interaction; illustrating the concept of design and layout rather than describing the interaction model, not displaying the operation of the system in detail, demonstrating the general feel and look of the users' interface, and simply illustrating the concept of general approach.

High fidelity prototype describes the system in more detailed. This prototype has a full interaction with the users where the users can enter data and interact with the system, representing the core functions that can simulate most of the functionality of the final system, and it has a very similar appearance to the actual product.

Features that will be implemented on the prototype system can be restricted with vertical or horizontal technique. Vertical prototype contains functionality detail but only to some selected features, not on the overall features of the system. Horizontal prototype includes all the features of the users' interface, but without its staple function the horizontal prototype is only a simulation and cannot be used to do the actual work.

The process of prototyping is a process which is interactive and repetitive. It combines the traditional development cycle. The prototype is evaluated several times before the end users state that the prototype is accepted. Figure 1 illustrates the process of prototyping:

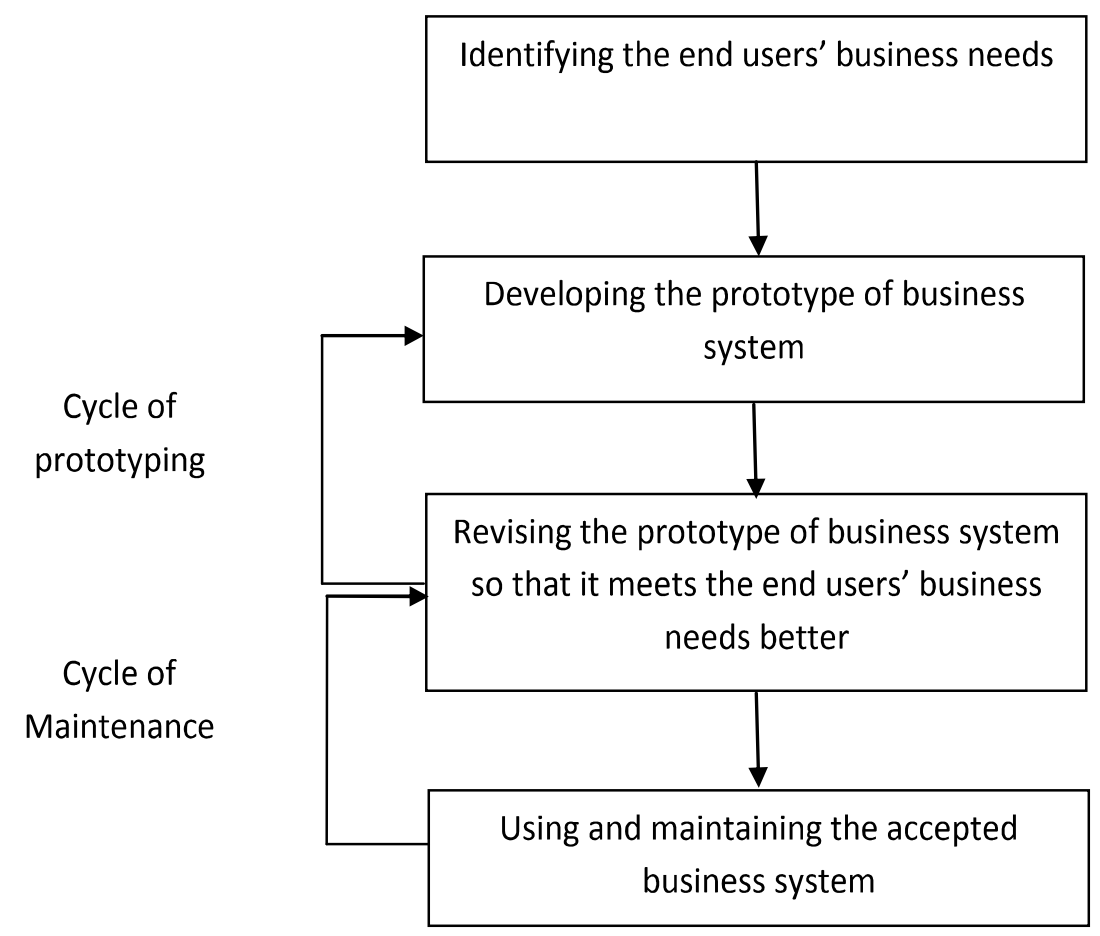

Figure 1. Stages of Prototyping

\subsubsection{System Requirements Analysis}


The development of information systems requires investigation and analysis of the reasons for the emergence of the idea to build and develop information system. The analysis is conducted to look at the various components used by the running system, which include hardware, software, network and human resources. The analysis also documents the activities of information system which include input, processing, output, storage and control. Furthermore, a feasibility study is conducted to formulate the required end-user information, resource requirements, costs, benefits and feasibility of the proposed project.

Analysis phase requires an evaluation system to determine the ability of the system to define what should be done by the system and then to determine the criteria to be met by the system. Several criteria that must be met include goal attainment, speed, cost, quality of information produced, efficiency and productivity, accuracy and validity and reliability 2001 [9].

\subsubsection{System design}

Analysis system describes what the system must do to meet the users' information needs. The system design determines how the system will meet these objectives. The system design consists of design activity that results in a functional specification. The system design can be seen as an interface design, data, and processes with an objective to produce specifications which fit product and method of the users' interface, database structure and processing and control procedures.

The system design will generate a prototype software package. A good product should include seven parts:

1) quick and easy menu features

2) input and output display

3) easily printable report

4) data dictionary that stores information on each field including the length of the field, editing in any report and used field format.

5) database with optimal key formats and record

6) appropriate display of the online query to the data stored in the database.

7) a simple structure with a programming language that allows the users to perform special processing, timing, automated procedures and others.

\subsubsection{Testing the Systems}

The prototype software packages are tested, implemented, evaluated and modified repeatedly until they are acceptable to the users. The system testing aims at finding errors that occur in the system and revise the system. This stage is important to ensure that the system is free of errors. The test system includes:

1) the testing of unit to test individual components independently without the other components of the system to ensure the correct operating system.

2) the testing of module which consists of interconnected-components.

3) the testing of sub-system which consists of several modules that have been integrated.

4) the testing of the system to find errors resulting from the interaction between subsystems and interface and to validate functional and non-functional requirements.

5) the testing of acceptance with the data entry by the users and not simulation data testing. 
6) documentation by recording every stage of the work from the beginning to the end of programming.

The web-based information system testing can use the techniques and methods of traditional software testing. The Web application testing includes testing the links, browser testing, usability testing, load testing, stress testing and malar testing.

The users' acceptance of the system can be evaluated by measuring the satisfaction of users to the system being tested. The satisfaction measurement system includes display, conformity with user needs, and speed and accuracy of the system to produce the desired information user. There are several models of user satisfaction measurement of the system, including the Technology Acceptance Model (TAM), End User Computing (EUC) Satisfaction, Task Technology Fit (TTF) Organizational Analysis and Human Technology (HOT) Fit Model.

One of the measurement models which has been translated into several different languages and does not show a significant difference in the measurement results is End User Computing (EUC) Satisfaction. This model emphasizes the satisfaction of users of the technology aspects which include those of content, accuracy, format, timing and ease of use of the system.

\subsubsection{Implementation}

Once the prototype is accepted, the implementation of the system is ready for operation and further the learning process of the new system takes place. Then it is compared with the old system in terms of technical and operational evaluation, user interactions, and information system and technology.

\subsubsection{System Design Tools}

System design requires equipment such as process design tools and data design tools. The former consist of a data flow diagram and a flow diagram of the system whereas the latter include entity-relationship diagram and data dictionary.

\subsubsection{Data Flow Diagram}

Data flow diagram (data flow diagram / DFD) is a chart documentation tool that uses symbols to explain a process. This chart shows the process flow of the entire system to the user and can be set according to the capability of understanding the details of the user. DFD consists of three elements: environment, processing, data flow and data storage. One advantage of using DFD is easier for users that are less mastered the field of computers to understand the system that is to be done 2005 [10].

\subsubsection{System Flow Chart}

System Flow chart is a device which is to describe the system in detail to illustrate the flow of information system and the system flow chart to illustrate the flow of the program.

\section{Research Method}


This research employed the action research method as to achieve its objective, namely: the development and the optimization of application of accounting information system with Rapid Application Development (RAD). In the first phase, a study was performed on the developed models. Based on the result of the preliminary research, a model of development of accounting information system with Rapid Application Development (RAD) was formulated. This research used the focused discussion group analysis technique. The FGD was held in Klaten, Central of Java, with 20 participants consist of academics, SME and Dinas UKM. Products from SME consist of food entrepreneurs, stationery, and t-shirts.

\section{Result}

The SME until recently have adequately thrived, especially those managed by young entrepreneurs who dare to start an independent online business. They have been challenged to create employment opportunities, not just as a job seeker force. Those above 40 years old have started to open SME since the provision of formal sector employment begins to shrink, forcing them to dare to open an independent business, in addition to hereditary business reason especially in the field of traditional food business.

The greatest constraint perceived is the limited skills of the human resources, both managers and business owners, especially in the areas of accounting and finance. In terms of accounting and finance, so far, only a manual conventional recording with a simple bookkeeping has been performed, not detailed computerized recording system assisted with detailed and accurate accounting system. Such simple recording cannot provide accurate financial information. Most SME do not understand what accounting system is and how to run it for business continuity.

For those aged over 40 years old who run SME, the procurement of computer equipment or supporting facilities is still regarded as an onerous burden of investment cost as many of them feel that such support device is not required yet, and they also find it difficult to operate the device due to their educational background. In majority, they feel more comfortable with the conventional recording system as they do today.

There has not been a separation between the operational expenses of the enterprises and the expenses for personal interests. Some owners of SME acknowledge that they still pay their personal expenses with the money of their enterprises whenever they need, and they frequently forget to record the expenses. Financial records are still complicated. It is, therefore, difficult to evaluate to what extent the SME have experienced business development because the financial records are not clear and accurate. The growth potential of the business is only judged on the basis that the enterprises "can survive and meet their need". This is mainly experienced by SME of traditional food.

The development of accounting information system for SME meets some challenges and urgencies, namely: (a) the improvement of skills of the human resources of SME in using the computerization facility, (b) the capital for procurement or investment of computer and accounting system, and (c) The mentoring of the relevant authorities so that the management of SME is sustainable, performs smoothly as expected and there is not momentum period.

\section{Conclusion}

The management of small and medium enterprises (SME) still uses a manual or conventional system. The skills to conduct a good accounting information system in accordance with the standard are limited. The development of accounting information 
system for SME encounters some challenges and urgencies. They include (a) the improvement of skills of the human resources of SME in using the computerization facility, (b) the capital for procurement or investment of computer and accounting system, and (c) The mentoring of the relevant authorities so that the management of SME is sustainable, performs smoothly as expected and there is not momentum period.

\section{References}

1. K. Mizunoura. Accounting Standards for Small- and Medium-Sized Enterprises in $A S E A N$. ERIA

Research Project FY2015 No.22. (C) Economic Research Institute for ASEAN and East Asia (2017)

2. Z.Baridwan, Akuntansi Keuangan Menengah: BPFE (1996)

3. HM, Jogiyanto. Sistem Informasi Akuntansi Berbasis Komputer. Yogyakarta: BPFE (1998)

4. HM, Jogiyanto. Pengenalan Komputer: Dasar Ilmu komputer, pemrograman, sistem (2000) informasi dan inteligensi buatan. Yogyakarta: Andi Offset

5. HM, Jogiyanto. Analisis dan Desain Sistem Informasi. Yogyakarta: Andi Offset (2005)

6. W.W.Winarno. Sistem Informasi Akuntansi. (1994)

7. Whitten, Jeffrey L., Bentley, Lonnie D, Dittman, Kevin C. Systems Analysis and Design Methods, edisi ke-6. Mc.Graw-Hill, New York.(2004)

8. O'Brien, J.A. Introduction to Information System: Essential for the E-Business Enterprise, $11^{\text {th }}$ edition. Mc. Graw Hill, New York. (2003)

9. B.Ladjamudin, Al-bahra.. Konsep Sistem Basis Data dan Implementasinya. Yogyakarta: Graha Ilmu (2005)

10. L.Raymond. Sistem Informasi Manajemen, edisi Indonesia, edisi ke-7, jilid 2. Terjemahan Teguh, Hendra dan Sukardi, Hardi. PT.Prehallindo, Jakarta. (2001) 